\title{
PREFERENCES OF CHILDREN'S RELIGIOUS INTERFAITH MARRIAGES: CASE STUDY IN THE INTERNATIONAL CONFERENCE ON RELIGION AND PEACE (ICRP)
}

\author{
Rosdiana, Ahmad Bahtiar
}

Faculty Sharia \& law, UIN Syarif Hidayatullah Jakarta, Indonesia

Email: rosdiana@uinjkt.ac.id, ahmad.bahtiar@uinjkt.ac.id

DOI: $10.21154 /$ justicia.v17i2.1967

\begin{tabular}{l|l|l}
\hline Received: 12 April 2020 & Revised: 1 Sept 2020 & Approved: 15 Oct 2020
\end{tabular}

Abstract: This research focuses on normative juridical aspects related to the tendency of religious selection in children as a result of Interfaith Marriage (PBA). With the approach of the sociology of religion and the psychology of child development, this study looks at how the pattern of children's education influences the tendency of the child's selection. Research informants are four PBA pairs taken randomly in the International Conference on Religion and Peace (ICRP) organization. The research findings explain that children's religious preferences follow the path and parenting patterns of their parents who have different religions. In this study there were at least three parenting practices applied by parents of interfaith marriages. First, parents of married couples of different religions teach two religious teachings at once. Secondly, one of the couples from interfaith marriages took over the child's religious education so that the children followed their religion. Third, an agreement to make one child join each parent's religion. The pattern of nurture and religious environment that is applied by interfaith married couples to their children, related to religion, is very influential in the development of children's religious understanding. Religious education that is tolerant and understands religious plurality is a basic basis so that children are not trapped in psychological conflicts blaming one of their parents' religions. This research is expected to contribute to the development of family law, particularly law on protecting children.

Abstrak: Penelitian ini memfokuskan pada aspek yuridis normatif terkait dengan kecenderungan pemilihan agama pada anak hasil Pernikahan Beda Agama (PBA). Dengan pendekatan sosiologi agama dan psikologi perkembangan anak, penelitian ini melihat bagaimana pola pendidikan anak yang berpengaruh terhadap kecenderungan pemilihan anak tersebut. Informan penelitian adalah empat pasangan PBA dalam lingkungan organisasi International Conference on Religion and Peace (ICRP) yang dipilih secara random. Temuan penelitian menjelaskan bahwa preferensi agama anak mengikuti alur dan pola pengasuhan kedua orang tua mereka yang berbeda agama. Hasil penelitian menunjukkan bahwa ada tiga pola asuh yang diterapkan oleh orang tua pernikahan beda agama. Pertama, orang tua dari pasangan nikah beda agama mengajarkan dua ajaran agama sekaligus. Kedua, salah seorang pasangan dari pernikahan beda agama mengambil alih pendidikan agama anak agar anak-anak mengikuti agamanya. Ketiga, kesepakatan untuk menjadikan salah satu anak ikut agama masing-masing orang tua. Pola pengasuhan dan lingkungan keagamaan yang diterapkan oleh pasangan nikah beda agama kepada anak-anak mereka, terkait dengan agama, sangat berpengaruh terhadap 
perkembangan pemahaman agama anak-anak. Pendidikan agama yang toleran dan memahami pluralitas agama menjadi basis dasar agar anak-anak tidak terjebak dalam konflik psikologis menyalahkan salah satu agama orang tuanya. Penelitian ini diharapkan memberikan sumbangsih bagi pengembangan hukum keluarga, khususnya hukum perlindungan terhadap anak.

Keywords: Religious Preference Children; Interfaith Marriage; ICRP.

\section{INTRODUCTION}

Interfaith marriage or mixed marriage $(\mathrm{PBA})^{1}$ becomes a phenomenon of complex debate in marriage issues. Legal policy and PBA implementation in Indonesia become unfinished problems, especially, political civil rights as one of the problems occured in interfaith marriage ${ }^{2}$ concerning marital status, inherited assets, wedding records, and marriage guardian status ${ }^{3}$.

Indonesia has a marriage Constitution (Law of The Republic of Indonesia Number 1 of 1974); however, that constitution has not accommodated the legal policy of interfaith marriage ${ }^{4}$. Scholars and practicians in the law differ in interpreting the formation of the articles relating to PBA; it is due to the unclear formation of the articles, which causes many interpretations ${ }^{5}$.

Although MUI's fatwa of 2005 forbids interfaith marriage according to many considerations, the number of PBA's doer has increased from year to year. In 1970, it recorded 10 cases of PB in Jakarta, then increased until 80 cases in 1979, and in 1986 reached 491 cases $^{6}$. Ahmad Nurcholish (2015), as an activist and PBA's doer, also said that until 2015 at least 638 couples throughout Indonesia were held PBA. Of the whole total, PBA's doers are dominated by the believer of Muslim-Christian (48\%), Muslim-Catholic (42\%), and 10\% are the believer of Muslim-Hindu, Muslim-Buddhist, Muslim-Confucian, Christian-Buddhist, Christian-Hindu, and Christian-Confucian. From geographic aspects, the implementation on PBA happened in Jabodetabek (20\%), Middle Java (19\%), Yogyakarta (15\%), East Java $(14 \%)$, Bali (14\%), South Sulawesi (10\%), East Kalimantan (6\%), Sumatera (1\%), and East Nusa Tenggara $(1 \%)^{7}$. These figures showed that PBA's implementation

Further abbreviated into PBA.

2 Ian Brown Lie, Dokumen-dokumen Pokok Mengenai Hak Azasi Manusia (Jakarta: Universitas Indonesia, 1993) : 178 .

3 Sonny Desi Judiasih, Nazmina Asrimayashab \& Luh Putu Sudini, "Prohibition of Intera Religion Marriage in Indonesia," Jurnal Dinamika Hukum 19, no. 1 (2019): 186-203.

4 Sri Wahyuni, "Politik Hukum Pernikahan Beda Agama Di Indonesia," Jurnal Pusaka 2, no. 2 (2014): 4-15.

5 Sarifudin, "Kawin Beda Agama dalam Kajian Hukum Islam dan Peraturan Perundang-Undangan di Indonesia," Al-Istinbath Jurnal Hukum Islam 4, no. 2 (2019): 213-30.

6 M. Hasyim Syamhudi, "Rumah Tangga Beda Agama: Konstruksi, Struktur dan Relasi Antar Penganut Agama dalam Keluarga Muslim Tionghoa Probolinggo Jawa Timur" (Dissertation, IAIN Sunan Ampel, 2010).

7 Ahmad Nurcholis, "Interfaith Marriage in The Constitution and The Islamic Law Dinamics in Indonesia," Al-Mawarid Journal of Islamic Law 15, no. 1 (2015): 123-142. 
in Indonesia does not only increase from year to year but also spread almost in the remote area of Indonesia.

The doers of PBA seek legal recognition to minimize the harmful impact of the marriage. ${ }^{8}$ One way is by arranging a marriage under an organization such as ICRP (International Conference on Religion and Peace). ICRP is an organization incorporated foundation which is non-sectarian, non-profit, non-government, and independently engaged in the interfaith field and dialogue of religions. Except for legal recognition, it is also vital to guarantee the rights of both the doer and the child resulting from the marriage based on administrative system and constitution, leading to the need for written documents of PBA's doer'.

One of PBA's implications is the choice of children's religion because the child faces the reality of their parent's different religions. At the same time, someone's belief is something very principal ${ }^{10}$. The problems appear due to the sense of ego from the parents toward children to follow parents' religion, either from husband or wife ${ }^{11}$.

Law of The Republic of Indonesia Number 23 of 2002 article 42 about child protection stated that every child acquires the protection of worship according to his religion before the child can decide his choice; furthermore, the religion embraced by the child follows his parent's religion. The explanation under the constitution of child protection article 42 paragraph 2 explains that a child can decide his/ her religion if the child has been rational and responsible, also fulfill prerequisites and procedures according to choosing religion and appliying regulation of the constitution.

Interfaith couples must be ready for the various problems as consequences of doing PBA. In PBA, sometimes a paltry subject can trigger disputes and problems ${ }^{12}$. Every little problem, in this case, not only occurs in Indonesia, which adheres to eastern culture and positions the religion as an essential factor in daily life, however, in the United States, according to Rozakis (2001), interfaith couples face many problems also ${ }^{13}$. It is in line with Horowitz (1999), which stated that problems encountered by interfaith couples in America are the negative reaction from family and surroundings ${ }^{14}$. Even, indeed, social and psychological problems

8 Dian Septiandani, Dharu Triasih, \&Dewi Tuti Muryani, “Legal Formulation of Marriage of Different Religions For The Benefit of Society," "Law Journal 1, no. 2 (2017): 171-79.

9 Ermi Suhasti, Siti Djazimah, \& Haritini, "Polemics on Interfaith Marriage in Indonesia Between Rules and Practices," Al-Jāmi'Ah: Journal of Islamic Studies 56, no. 2 (2018): 390-91.

10 M. Hasyim Syamhudi, "Rumah Tangga Beda Agama: Konstruksi, Struktur dan Relasi Antar Penganut Agama dalam Keluarga Muslim Tionghoa Probolinggo Jawa Timur." (Dissertation, IAIN Sunan Ampel, 2010).

11 J.E Marcia, Ego Identity, (New York: Springer, 1993).

12 Recep Çiğdem. "Interfaith Marriage in Comparative Perspective". Acta Orientalia Academiae Scientiarum Hung. Vol. 68 (1), (2015). 59-86.

13 L. Rozakis, Interfaith Relationship (Indiana: Macmilan, 2001).

14 June Andrew Horowitz, "Negotiating Couplehood: The Process of Resolving December Dilemma 
are not only faced by two people as interfaith couples but also the children of PBA as a result, more or less, will meet the impacts. ${ }^{15}$ They likewise happened in other places. The family who was doing PBA in India is considered as "different" compared to other families. There is still existed in the societies toward PBA's family ${ }^{16}$.

There is much discussion about the study related to PBA. For instance, the research was conducted by A. Chaeruddin in "Law of The Republic of Indonesia Number 1 of 1974 and Relation to marriage between people of different religions (the study of juridical, implementation, problematic, also Islamic law contribution in development and reform of national law)"17. Through the sociolegal-religious law - integrated analysis method, the research shows that PBA is regulated implicitly in Law of The Republic of Indonesia in article 2 paragraph (1) juncto article $8 \mathrm{sub}$ (f) juncto article 66, inferred (verwijzingsregel) on the law of each religion and belief.

Furthermore, Alvina Suwasiswahyuni's research entitled “validity of interfaith marriage took place overseas that is based on Law of The Republic of Indonesia Number 1 of 1974 about marriage and Law of The Republic of Indonesia Number 23 of 2006 on demography administration"18. By applying the normative juridical approach and juridical analysis, this research shows that marriage registration abroad is only to fulfill the legal requirements of Law of The Republic of Indonesia article 56 about demography administration, however, it does not determine whether the marriage is legal or not. Those are asserted by Zuriyati, Yaswirman, dan Yasniwati (2019). ${ }^{19}$ PBA arranged abroad primarily is contradicted with international civil law principles and Indonesia's positive law ${ }^{20}$.

Salma's research "Interfaith marriage after the enactment of Law of The Republic of Indonesia Number 1 of 1974 on marriage" 21 focuses on the implementation and PBA's consequence after the constitution of marriage has

among Interfaith Couples," Family Process 38, no. 3 (1999): 303-323.

15 M Rosenbaum, Cellebrating Our Differences: Living Two Faith in One Marriage (Philadelphia: Beidel Printing, 1999).

16 Shewata Verma and Neelam Sukhramani, "Interfaith Marriages and Negotiated Spaces," Society and Culture in South Asia 4, no. 1 (2017): 16-43.

17 Ahmad Chaeruddin, "Undang-Undang No. 1 Tahun 1974 dan Kaitannya dengan Perkawinan Antar Orang yang Berlainan Agama: Kajian Yuridis, Implementasi, Problematika dan Kontribusi Hukum Islam dan Pembangunan dan Pembaharuan Hukum Nasional" (Dissertation, IAIN Syarif Hidayatullah Jakarta, 2000).

18 Alvina Suwasiswahyuni, “Keabsahan Perkawinan Beda Agama yang Dilangsungkan di Luar Negeri Berdasarkan Undang-Undangn No. 1 Tahun 1974 Tentang Perkawinan dan Undang-Undang No. 23 Tahun 2006 Tentang Administrasi Kependudukan" (Thesis, Universitas Indonesia, 2012).

19 Zuriwati, Yaswirman,\& Yasniwati "Registration of Interfaith Marriages at the Civil Registry Office in Pekanbaru," International Journal of Multicultural and Multireligious Understanding 6, no. 5 (2019): 895900.

20 Benny Krestian Heriawanto, “Interfaith Marriages Based on Positive Law in Indonesia and Private International Law Principles.," UNIFIKASI : Jurnal Ilmu Hukum 6, no. 1 (2019): 94-100.

21 Salma, "Perkawinan Campuran Antar Agama Setelah Berlakunya Undang-Undang No. 1 Tahun 1974 tentang Perkawinan" (Thesis, Universitas Diponegoro, 2002). 
been passed. The research concludes that generally all of the religions agree on the validity of PBA if both couples have the same religion, it means that one partner must convert his religion according to his partner's religion. It is in line with Nugraeni ${ }^{22}$.

PBA's legal policy in Indonesia studied by Anthin Latifah “Interfaith marriage in Middle Java: The study about legal policy toward the implementation of Interfaith marriage in Middle Java." This research was managed to implement PBA in the County of Middle Java and the views of several religious leaders regarding these issues ${ }^{23}$. In the study of Rosdiana, Saumin, \& Maisarah, religious leaders in each religious council have different views regarding PBA. The constitution governing the issues are passed before religious councils are formed. Therefore, there is no role in the religious council in the formation of the constitution $^{24}$.

Next is Muhammad Ashsubli research titled "The Constitution of the Marriage in The Plurality of Religious Laws: Judicial Review of The Article of Interfaith Marriage." 25 This research discussed the development of marital laws, especially about PBA, in the views of religious laws.

The research discussed legal recognition was conducted by Kadek Wiwik and Aloysius entitled "The Role of The State in Providing Legal Protections for The Candidates of Interfaith Marriage in Indonesia" ${ }^{26}$. In the PBA's case, the researcher sees that the state only records the marriage, or regulates the aspect of marital administration. Through this empirical approach with the sample of PBA's doer in Denpasar and Bogor, this research concludes that the obscurity of PBA law rules in Indonesia leads to Judge decision in providing marital stipulation.

The solution toward PBA's problems was is revealed by Nasir (2020). The researcher saw how the problems regarding PBA in Lombok can be solved through institutional authority and personal autonomy. The institutional authority is the power structure established by the state to serve the interest of the society, namely inter-religious interaction problems, including the marriage of the Muslim-Hindu community that often occurs there. Besides, the compromises were made in the

22 Prasasti Dyah Nugraheni, “The Implementation of Marriage Different Religion and Their Due To The Law of The Religion of Marriage Status," Law And Justice 4, no. 2 (2019): 68-82.

23 Anthin Latifah, "Perkawinan Beda Agama di Jawa Tengah: Kajian Kebijakan Hukum Terhadap Pelaksanaan Perkawinan Beda Agamadi Beberapa Wilayah di Jawa Tengah," Laporan Penelitian Kemenag, 2015.

24 Rosdiana, Ummu Hanah Yusuf Saumin,\& Masayu Mashita, “Legitimacy on Inter-Fath : Marriages: An of the Role Religious Council on the Legal Policy in Indonesia," Ahkam: Jurnal Ilmu Syariah 19, no. 1 (2019): 81-96.

25 Muhammad Ashsubli, “Undang-Undang Perkawinan dalam Pluralitas Hukum Agama: Judicial Review Pasal Perkawinan Beda Agam," Jurnal Cita Hukum 2, no. 2 (2015): 289-302.

26 Kadek Wiwik Indrayanti dan Aloysius R. Entah, "Peran Negara dalam Memberikan Perlindungan Hukum bagi Calon Pasangan Kawin Beda Agama di Indonesia," Jurnal Hukum dan Pembangunan 45, no. 3 (2015): 408-30. 
various norm, regulations, and local wisdom formulated and approved by related parties who were experiencing the conflicts due to $\mathrm{PBA}^{27}$.

The researches related to PBA have not yet focused on the tendency of a child's religious choice. During this time, the researcher highlighted the phenomenon of Interfaith marriage in Indonesia from the legal and legality aspects also marital constitution impacts in 1974. Although the other aspects are no less critical, that is related to the children acquired from interfaith marriage from the perspective of the sociology of religions, especially that is related to the extent to which the sociological, religious reality of children toward their daily life practices.

Based on several references of the research, the research uses the qualitative method provides the novelty and completes previous research by providing the other perspectives of views called child's religious preferences from interfaith marriage in Indonesia, by the case study of interfaith marriage doer in ICRP. The data came from the interview with four PBA's couples and some ICRP administrators in May-August 2018.

This research is expected to either contributing to developments of family laws, particularly child protection law, also the reference on research and policies for PBA-related parties, particularly the preference of religions on children resulted from interfaith marriages.

\section{THE PREFERENCE OF CHILDREN' RELIGION DISCUSSION IN INTERFAITH MARRIAGE}

The following is a discussion about the child' religious preference of several couples that become the informants of this research. A glimpse of ICRP and data of some informants regarding their profession, Islamic education, culture, and other supporting factors of their marriage. This research focuses on the normative juridical aspects related to child's (resulted from interfaith marriage) tendency of choosing the religion. By religious sociology approach and child development psychology, this research sees how the educational pattern on the children affecting to child's tendency to choose the religion. The informants are interfaith couples in the organizational environment in International Conference Religious and Peace (ICRP).

\section{A glimpse of ICRP and The Data of Informants}

Interfaith leaders established ICRP (International Conference on Religion and Peace). ICRP attempts to spread the tradition of dialogue in humanistic and pluralistic religious life development in the homeland. This organization is located

27 Mohamad Abdun Nasir, "Religion, Law, and Identity: Contending Authorities on Interfaith Marriage in Lombok, Indonesia," Journal Islam and Christian-Muslim Relations, 31, no. 2 (2020): 131-50. 
in Cempaka Putih Barat street XXI Number 34 Central Jakarta.

Far before ICRP inaugurated on July 12, 2000, by Abdurrahman Wahid as President of the Republic of Indonesia, the attempts of inter-religious dialogue have grown and developed in Indonesia. ICRP is established so that the dialogues can be expanded and developed. Except for the contribution to the development of peace studies and conflict resolutions, this organization collaborates with the religious organization and inter-faith and individuals. In addition, ICRP is also actively involved in networking with the organization, which concern about fighting for pluralism and peace against injustices systems of social, gender, and human rights ${ }^{28}$.

The current chief or ICRP, Mohammad Monib, is known as a private headman specializing in interfaith. On the official website of ICRP, Monib is often asked to marry off the interfaith couples abroad. ${ }^{29}$ However, there is no official release from ICRP related to annual data regarding the implementation of interfaith marriage advocacy.

Based on the interview with Mohammad Monib, it is known that three headmen often marry off interfaith couples in ICRP encompassed Imdadun Rahmat, Ahmad Nurkholis, dan Mohammad Monib himself. On average, they marry off five couples every month. According to him, on average, 150 couples are married off by the ICRP per year ${ }^{30}$.

The advocacy and aid to interfaith couples who want to marry are that the ICRP does not handle this activity structured. It means that ICRP only delegates the individual to marry of the interfaith couples.

In this research, the researcher has chosen four informants using a random sampling method. It means that no specific specifications and criteria in determining the informant. The only consideration is that these interfaith couples are married off or advocated by ICRP. Even though, as explained before, officially, ICRP does not have a direct connection with interfaith marriage.

Four cases of interfaith marriage highlighted in this research are that it was experienced by NP, AO, TS, and AN. NP is a 30-year-old Hindu woman. NP married an Islam man in which they have two children. She was born in Denpasar on August 8, 1988. The background of her religion is Hindu, which she was born as a large Hindu family. From childhood until graduated from high school, she spent all of her life in Denpasar, Bali. Then, she pursued a higher education level and had worked in Jakarta.

In the first meeting, NP and her husband were colleagues in a company in

\footnotetext{
28 "Profil ICRP," icrp-online.com, 2017.

29 "Penghulu Beda Negara Lintas Agama," icrp-online.com, 2017.

30 “Interview with Mohamad Monib," 10 Oktober 2017.
} 
which NP's husband is her boss. Then, they were in a relationship or dating for one and a half year. Because they were feeling compatible with each other, both of them decided to get married ${ }^{31}$.

The second research subject was AO. She is an Islam woman who was born in Padang on July 5,1979, and graduated from her study until senior high school in her hometown. She was in Islamic Boarding School for one year, but she decided to left out her Islamic Boarding School. Then, she transferred to a public school. NP comes from a fairly devout Muslim family in Padang.

AO's husband is Confucian. The closeness of AO and her husband started from a business cooperation relationship. AO's husband is an entrepreneur in the health sector, while AO herself is a doctor in a clinic. Because of the long relationship, $\mathrm{AO}$ and her husband decided to continue their relationship up to marriage ${ }^{32}$.

The second research subject was TS, a 38-year-old catholic woman. She was born in Jakarta on January 8, 1980. Different from other research subjects that did not come from the inter-religion family, TS was born and raised amidst a multireligion family. Her parents are the doer of interfaith marriage. In other words, TS is the second generation of interfaith marriage doers in Indonesia.

Of TS's background as an attorney, it delivers her on a legally conscious environment. TS was fully aware of no restrictions in interfaith marriages, considering her family background and her understanding that marriage law still has multiple interpretations. TS's husband is a Muslim and worked as an employee in a private company. TS and her husband were friends during college; even they had dated from college. Because it was difficult to get parents' blessing, they dated for almost six years ${ }^{33}$.

The last research subject is $\mathrm{AN}$, who becomes a counselor of the couples who want to conduct interfaith marriages. In this research, AN is informant, doer of interfaith marriage, as well as interviewees from ICRP. AN married Confucian woman in 2003. At that time, he has been a part of ICRP. The news then spread nationally, which leads him to a figure who was praised and reviled.

As a doer also counselor, AN has worked a lot in the world of PBA. Until this time, 2018, at least 898 interfaith couples were helped by $\mathrm{AN}^{34}$.

Of the four key informants who were the research subjects, all of the interfaith couples are at an adequate economic level; in other terms, they are an upper middle class. This situation is understandable because interfaith marriage

\footnotetext{
31 “Interview with NP by phone," 06 Oktober 2018.

32 "Interview with AO by phone," 05 Oktober 2018.

33 "Interview with TS by phone," 06 Oktober 2018.

34 "Interview AN byphone," 06 Oktober 2018.
} 
is not only faced by the psychological and social side but also the financial side. Interfaith couples must bear the costs and go through procedures that are different from other couples. It does still not include a wedding reception and others.

The background of the research subjects varied. Some of them come from devoutly religious families, such as $\mathrm{AO}$ and $\mathrm{AN}$. Both of them admit as Islamic students in which some of them come from ordinary families, in other words, not overly emphasizing religious teaching. Like TS, her family background is the doers of interfaith marriages. Therefore, it is unsurprising that TS also did an interfaith marriage. In a sense, his family fully supports what TS wants to do with her interfaith partner.

On the other hand, each informant comes from a different culture. The relation of inter-culture marriage carries a risk that deserves attention. One of them is the possibility of enormous conflict potential in marriage compared to the same cultural marriage (endogamy) ${ }^{35}$. The informants of this research come from Padang and Java, in which socially it is closer to the culture of Islamic students. Thus, some of them come from Hindu Bali and cosmopolitan Jakarta. However, from all of the social and cultural background of informants, all of them got married around Jabodetabek. Therefore, social-culture brought by informants has more or less merged by cosmopolitan culture, which inherent with Jakarta. It means that open-minded and tolerant tradition has built in Jakarta's environment. The individualistic social condition of Jakarta is more or less contributed to determining interfaith marriage decisions. In other words, The informants' household affairs are not interfered with by the surroundings, or this is even tolerable. It shows that those regions with higher levels of ethnic heterogeneity also have higher rates of inter-ethnic and inter-religious marriages and that there is a significant correlation between the prevalence of interethnic and interfaith marriages at the provincial level ${ }^{36}$.

Four informants researched, all of the bases on their marriage according to human nature, namely love and accept each other. The difference in religion is not a significant obstacle for them to build a family. All of the informants admitted that to undergo a love in interfaith marriage is not an easy situation to go through. However, since they believe the goodness of universal teaching of the religion, in the end, a love factor becomes the essential factor, and as admitted by the informants, that is what becomes a foundation to do interfaith marriage.

Family's supporting factor is also essential in an interfaith marriage. It is like

35 Anselmus Agung Pramudito, “Merenda Cinta Melintas Budaya Hingga Senja Tiba (StudiLiteratur Tentang Perkawinan Antar-Budaya)," Buletin Psikologi 25, no. 2 (2017): 76-88.

36 Noryamin Aini, Ariane Utomo, \& Peter MacDonald“Interreligious Marriage in Indonesia," Journal of Religion and Demography 6, no. 1 (2019): 208-9. 
TS, who comes from an interfaith family. In this interview, when TS was asked about the family who married inter-religion couples, she said: ${ }^{37}$

"There are a lot. Three cousins of mine married interfaith people, including my parents, who are in an interfaith marriage. I, myself, follow my father's religion, catholic. My sister is Muslim; she follows my mother's religion."

The openness principle in understanding religion also becomes the third important factor in the occurrence of interfaith marriage. The people with strong beliefs presume that son or daughter who married a Christian is more negative. Otherwise, Muslim families who presumed that Islam and Christian have many similarities (compared to differences) do not oppose PBA for their children, both male and female child ${ }^{38}$.

In the case of $\mathrm{AO}$ and $\mathrm{AN}$, for instance, both of them are devout Muslims. However, their belief in religion does not prevent them from marrying off people in inter-religion. AO stated the argument as follows: ${ }^{39}$

"I do believe that all of the religions teach good value. I know it because my husband is Confucian, but he is not fanatic about his religion, although previously I expected my husband going to follow my religion. However, because of the initial commitment, we will accept the consequences and will not force each other's religions, so we enjoy to undergo our days together until we have two children. Alhamdulillah, my husband believes me to hand over the children's education. Furthermore, all of my children are educated to understand the Islam religion, but still a tolerant and pluralist Islam."

However, religious education of the spouses in an interfaith marriage or one of them is not too deep or called lay in religious issues. In this case, one of the spouses is susceptible to change his religion by following his religion's partner. In the survey, almost $80 \%$ of the spouses who changes his religion into Christian because of marriage. A respondent who comes from a Muslim family said that religion is an essential component in marriage life. This respondent married to the Christian he dated ${ }^{40}$.

\section{Parenting and Preference of Child Religion from Interfaith Marriage (PBA)}

Overall, the parenting style practiced by interfaith married couples, as represented by the research subjects, is the same as families in the same religions. However, the differences are in the teaching of religion, whether the children

\footnotetext{
37 "Interview with TS by phone." 06 Oktober 2018.

38 Jan van Niekerk and Maykel Verkuyten Niekerk, "Interfaith Marriage Attitudes in Muslim Majority Countries: A Multilevel Approach," The International Journal for the Psychology of Religion, 28, no. 4 (2018): 257-70.

39 "Interview with AOby phone," 05 Oktober 2018.

40 Myengkyo Seo, "Falling In Love and Changing Gods Inter-Religious Marriage And Religious Conversion in Java, Indonesia," Indonesia and the Malay World 41, no. 119 (2013): 76-96.
} 
follow their father or mother. It is decided by the initial commitment of each interfaith couple.

Based on the research subject acknowledgment, three parenting differences are related to the teaching of religious values on children. First, the interfaith couples teach their children two religious teachings at once. In AN's case, for instance, he and his wife teach their children the value of Islamic religion and Confucian at once. The openness from AN and his wife triggers a harmony in their family. In the case of AN, his environment and wife support them to be open to each other. AN's acknowledgment: ${ }^{41}$

"We are helped because my wife and I are both active in an interfaith institution. I introduce two beliefs to my children since they were young, I introduce Islam tradition, and their mother introduces Confucian tradition. What we taught them is what our children then absorbed, and in fact, they could identify that they were children of interfaith marriages."

Second, one of the interfaith couples takes over a child's religious education in order to follow his religion. It appears from AO's case, who educated Islam religion to her children because her husband, who is Confucian, believes her to teach the religion. AO's children are still educated in open and tolerant religious teachings. As he admits: ${ }^{42}$

"I teach my children a tolerant and pluralist Islam teachings. My daughter is schooled in Catholic school; the reason is that the school is disciplined and of good quality. However, when she is in the home, I teach her the basics of religion. I ask her to pray, do Ramadhan fasting, and others. Nevertheless, I have been lived in the Islamic Boarding School for a while. More or less, I can teach the children about my religion. Because I, myself, is uncomfortable with Ustadz (Islamic teacher) in my area, they are too fanatic and often negate other religions."

Third, the agreement to make a child follow a parent's religion. It happened with TS, who is Catholic, and her husband, who is Muslim. TS has two children. The first child follows her husband's religion, which is Islam, and the youngest child follows her religion, which is Catholic.

Of three types and spiritual parenting applied by interfaith parents, each has the strength and the weakness. The strength of teaching two religions is the children can learn the teaching of two religions and understand each parents' religion based on knowledge, not only based on the observation. The weaknesses lay in child development in determining one of the religions he/ she believes. In the case of other research, it will occur a conflict toward the children to decide a religion.

41 “Interview with ANby phone," 06 Oktober 2018.

42 "Interview AOby phone." 05 Oktober 2018. 
Child involvement in knowing the interfaith family's religion, as depicted by the research subject, is not far from the children in general. Understandably, the world of the children is not disturbed by these religious differences. The process of parental involvement in teaching different religious values, as shown by AN and NP, for example, is a determining factor so that children can be able to understand that religious differences should not be a conflict between humans. In fact, their interfaith parents can live in harmony under one roof.

As far as the investigation of this research, parents in interfaith families, reflected in the cases of $\mathrm{NP}, \mathrm{AO}, \mathrm{TS}$, and $\mathrm{AN}$, admit that their children are educated to understand religions with universal teaching values. The children tend to follow their parents' willingness and religious teaching.

From three spiritual parenting, as explained in the previous section, so far, the children from those four families are still in their parents' control. The main highlight is in the first case; the parent taught two different religious teachings. However, it has not yet seen a conflict in children to choose one of the parents' religion. It is based on the research subject that the children have not yet mature and have not been able to decide for themselves what religion they want to adopt. In many cases, the children tend to adopt the mother's religious identity compared to the father's religious identity ${ }^{43}$.

It is different from second and third parenting in which the parents have decided their children's religion. For instance, NO's children have followed their mother's religion since childhood. Like TS's case, TS considered their children to follow one of their parents. The tendency to choose religion like this must be nurtured from an early age because the children in this parenting are only learned to practice one religion since their childhood.

Therefore, in these four cases of this research, the preference of a child's religion follows the flow and pattern of parenting of both interfaith parents. There are still no variables deviated from this parenting pattern.

As explained in the previous section, parents' parenting becomes the defining factor of child religious preference at least until childhood is over. Some research found that there is a correlation between marital quality and the environment of parenting. The quality of marriage influences the quality of the parenting environment. Meanwhile, the quality of spouse marriage and quality of the family's environment are a factor that will determine children's attitudes. Furthermore, the quality of the parenting environment is also influenced by the quality of marriage, the education of wife, family measurement, also the interaction between father dan children ${ }^{44}$.

43 Hart M Nelsen, “The Religious Identification of Children of Interfaith Marriages," Review of Religious Research 32, no. 2 (1990): 122-134.

44 Syariful Alam, “Reconstruction of Marriage Zonation In Islamic Law Perspective," Legality 2, no. 2 (2020): 168-69. 
From the perspective of psychology, as explained by Surbekti, the effect of the environment, especially family, is very dominant for the development of someone's religion. The children who have grown in the religious family are likely to be more religious. The children born in Islam family are likely to be a Muslim, which the children born in Cristhianist family are likely to be a Christian, and others ${ }^{45}$.

In the case of interfaith family's children handled by ICRP, all of them have the legal legality, as the acknowledgment by AN while interview. She said:46

"After the marriage was recorded, the couples got a marriage certificate. The marriage recorded is non-Islamic marriage because the Department of Population and Civil Registration only has the authority to record a marriage out of Islam. In Islam, married couples are recorded by the Religious Affairs Office (KUA). However, the Religious Affairs Office (KUA) does not accept the recording of interfaith marriage. In a marriage certificate, it is not written a partner's religion. With a marriage certificate, they can make Family Card, Child's Birth Certificate, and others. It must be noted that the marriage book is only made by the Religious Affairs Office (KUA) and is acquired if both married couples are Moslem. Generally, non-Islam couples have a marriage certificate. Meanwhile, in which one of the couples is Moslem, in an interfaith marriage, it is impossible to get a marriage book."

The information above states that interfaith married couples do not receive a marriage book. However, marital legality is only obtained from the Department of Population and Civil Registration, which it remains valid in the rules of state administration. Furthermore, their children still get legal rights from the state, such as birth certificates and others. Therefore, administratively, there are no obstacles or problems from interfaith parents under ICRP.

However, parents can not impose their children's tendency when they choose and decide what their religion is. It is regulated in the Law Number 35 of 2014 about the alteration on Law Number 23 of 2002 about Child Protection. In article 6 , it is mentioned that "Every child reserve the right to worship according to his religion, think, and express according to the level of intelligence and age under parents' or guardian's guidance."

Of the explanation of the abovementioned article 6, while the children are still under the guidance of their parents, they certainly deserve to decide their religion in which they will practice. In an interfaith marriage, the parents can not impose children's religion, such as in TS's case, which all of her children want to follow only one of the religions.

\section{The Preference of Children' Religion in Interfaith Marriage}

Children's involvement in the process of knowing the family's religion

45 Subandi, “Perkembangan Kehidupan Beragama," Buletin Psikologi 3, no. 1 (1995): 11-19.

46 "Interview withAN bytelepon." 06 Oktober 2018 
who are in an interfaith marriage, as depicted by the research subject, is not much different from the children in general. It means that different religion does not bother the children's world. Parents' involvement in teaching the different religions, as seen by $\mathrm{AN}$ and $\mathrm{NP}^{\prime}$ family, for instance, becomes defining factor so that the children understand that different religion does not become a conflict among humans. Indeed, their interfaith parents can get along well in one roof.

As far as the investigation of this research, parents in an interfaith marriage, which are reflected by NP, AO, TS, and AN, admit that the children are taught to understand universal teaching values. The children tend to follow each parent's willingness and teaching of their religions.

Of three spiritual parenting, as explained in the previous section, so far, the children of the four families are still under their parents' control. That it becomes main highlighted in the first case that the parents teach two different religions. However, there is no conflict within the child to choose between the two parents' religions. It is based on the research subject that the children are still less mature and can not decide their religion themselves. In several cases, the children tend to choose the mother's religion compared to the father's religion.

Another case is the second and third parenting in which the parents have decided their every child's religion. Like NP's case, for example, the children follow to believe in Islam as their mother's religion. Besides, in TS's case, she considers her children to follow one of the parents' religion. The tendency to choose religion like this has been nurtured since childhood. Therefore, the children in this parenting learn and practice a religion teaching from an early age.

Thus, in the four cases of this study, the children's religious preference are to follow the flow and patterns of their interfaith parents' parenting. It is not yet visible variables to deviate the parenting pattern. As explained in the previous discussion, parents' parenting becomes the defining factor of child religious preference, at least until childhood is over. From the perspective of psychology, as explained by Surbekti, the effect of the environment, especially family, is very dominant for the development of someone's religion. The children who have grown in the religious family are likely to be more religious. The children who are born in Islam family are likely to be a Muslim. Also, the children who are born in the Cristhianist family are likely to be Christian, and others ${ }^{47}$.

In the case of interfaith marriage handled by ICRP, all of them have legal legality, as AN's acknowledgment in his interview. He said:48

"After the marriage was recorded, the couples got a marriage certificate. The marriage recorded is non-Islamic marriage because the Department of Population

\footnotetext{
47 Subandi, "Perkembangan Kehidupan Beragama."Buletin Psikologi 3, no. 1 (1995) : 11-19.

48 "Interview with AN by phone." 06 Oktober 2018.
} 
and Civil Registration only has the authority to record a marriage out of Islam. In Islam, the married couples are recorded by the Religious Affairs Office (KUA). However, the Religious Affairs Office (KUA) does not accept the recording of interfaith marriage. A marriage certificate does not insert the status of a partner's religion. With a marriage certificate, they can make Family Card, Child's Birth Certificate, and others. It must be noted that the marriage book is only made by the Religious Affairs Office (KUA) and is acquired if both married couples are Moslem. Generally, non-Islam couples have a marriage certificate. Meanwhile, in which one of the couples is Moslem, in an interfaith marriage, it is impossible to get a marrriage book."

The information above states that interfaith married couples do not receive a marriage book. However, marital legality is only obtained from the Department of Population and Civil Registration, which it remains valid in the rules of state administration. Furthermore, their children still get legal rights from the state, such as birth certificates and others. Therefore, administratively there are no obstacles or problems from interfaith parents under ICRP.

However, parents can not impose their children's tendency when they choose and decide on their religion. It is regulated in the Law Number 35 of 2014 on the alteration in Law Number 23 of 2002 on Child Protection. In article 6 mentioned that:

"Every child reserve the right to worship according to his religion, think, and express according to the level of intelligence and age under parents' or guardian's guidance."

Of the explanation of the above mentioned article 6, while the children are still under the guidance of their parents, they certainly deserve to decide their religion in which they will practice. In an interfaith marriage, the parents can not impose children's religion, such as in TS's case, which all of her children want to follow only one of the religions.

By agreeing collectively, it is expected that PBA's families reach quality, satisfaction, and happiness; moreover, they can maintain the continuity of the marital relationship until the maturity phase arrives.

\section{CONCLUSION}

Based on this discussion, it can be concluded that parents' parenting taught to the children decide the preference of the child' religion of interfaith families. Based on the research, respondents from ICRP apply three parentings in teaching religion to their children. Related to that, ICRP advocates the interfaith marriage record, so that interfaith couples obtain the convenience in processing PBA's administration. It is according to Article 6 of the laws Number 5 of 2014 on child protection. 
Rosdiana \& Ahmad Bahtiar, Preferences of Children's Religious Interfaith Marriages ...

The parenting is applied by interfaith married parents in this research encompassing, firstly, the interfaith married parents teach the two religious teachings. Second, one of the interfaith couples takes over religious education so that the children follow his/her religion. Religious environment chosen by their parents, as explained in the first point, is much affected by the parenting pattern of interfaith families' children. The parenting applied by interfaith couples to their children, especially related to religion, is highly influential toward the development of a child's religious understanding. A tolerant religious education and which understands pluralism in religion become a fundamental base in order for the children do not be stuck in the conflict of psychology blamed to one of his/her parents' religions.

The next research recommendation is needed to research qualitatively by applying the survey on how far children do education in the case of interfaith marriage affect on the decision of the children in choosing the religion in the future. The challenge of interfaith couples is how to teach their children about tolerant religious understanding by the values of pluralism as a base. It is vital to prevent the conflict that will be faced by their children.

Moreover, it needs further research on how the individuals coming from interfaith families can undergo and comprehend their religion. In a sense, who becomes the research subject is an adult, not a child.

\section{REFERENCES}

\section{Journal}

Aini, Noryamin, Ariane Utomo, and Peter McDonald. "Interreligious Marriage in Indonesia." Journal of Religion and Demography 6, no. 1 (2019): 208-9.

Alam, Syariful. "Reconstruction of Marriage Zonation in Islamic Law Perspective." Legality 2, no. 2 (2020): 168-69.

Ashsubli, Muhammad. “Undang-Undang Perkawinan dalam Pluralitas Hukum Agama: Judicial Review Pasal Perkawinan Beda Agam." Jurnal Cita Hukum 2, no. 2 (2015): 289-302.

Chaeruddin, Ahmad. "Undang-Undang No. 1 Tahun 1974 dan Kaitannya dengan Perkawinan Antar Orang yang Berlainan Agama: Kajian Yuridis, Implementasi, Problematika dan Kontribusi Hukum Islam dan Pembangunan dan Pembaharuan Hukum Nasional." Dissertation,IAIN Syarif Hidayatullah Jakarta, 2000.

Heriawanto, Benny Krestian. "Interfaith Marriages Based on Positive Law in Indonesia and Private International Law Principles." UNIFIKASI : Jurnal Ilmu Hukum 6, no. 1 (2019): 94-100. 
Horowitz, June Andrew. "Negotiating Couplehood: The Process of Resolving December Dilemma among Interfaith Couples." Family Process 38, no. 3 (1999): 303-323.

Indrayanti, Kadek Wiwik dan Aloysius R. Entah. “Peran Negara dalam Memberikan Perlindungan Hukum bagi Calon Pasangan Kawin Beda Agama di Indonesia." Jurnal Hukum dan Pembangunan 45, no. 3 (2015): 408-30. Judiasih, Sonny Desi, Nazmina Asrimayashab \& Luh Putu Sudini. "Prohibition of Intera Religion Marriage in Indonesia." Jurnal Dinamika Hukum 19, no. 1 (2019): 186-203.

Nasir, Mohamad Abdun. "Religion, Law, and Identity: Contending Authorities on Interfaith Marriage in Lombok, Indonesia." Journal Islam and ChristianMuslim Relations, 31, no. 2 (2020): 131-50.

Nelsen, Hart M. “The Religious Identification of Children of Interfaith Marriages.” Review of Religious Research 32, no. 2 (1990): 131.

Niekerk, Jan Van and Maykel Verkuyten. "Interfaith Marriage Attitudes in Muslim Majority Countries: A Multilevel Approach." The International Journal for the Psychology of Religion, 28, no. 4 (2018): 257-70.

Nugraheni, Prasasti Dyah. “The Implementation of Marriage Different Religion and Their Due To The Law of The Religion of Marriage Status." Law And Justice 4, no. 2 (2019): 68-82.

Nurcholis, Ahmad. "Interfaith Marriage in The Constitution and The Islamic Law Dinamics in Indonesia,." Al-Mawarid Journal of Islamic Law 15, no. 1 (2015): 139. Pramudito, Anselmus Agung. "Merenda Cinta Melintas Budaya Hingga Senja Tiba (Studi Literatur tentang Perkawinan Antar-Budaya)." Buletin Psikologi 25, no. 2 (2017): 76-88.

icrp-online.com. "Profil ICRP," 2017.

Rosdiana, Ummu Hanah Yusuf Saumin, \& Masayu Mashita. “Legitimacy on Inter-Fath : Marriages: An Analysis of the Role Religious Council on the Legal Policy in Indonesia." Ahkam: Jurnal Ilmu Syariah 19, no. 1 (2019): 81-96. Sarifudin. "Kawin Beda Agama Dalam Kajian Hukum Islam dan Peraturan Perundang-Undangan di Indonesia." Al-Istinbath Jurnal Hukum Islam 4, no. 2 (2019): 213-30.

Seo, Myengkyo. "Falling In Love and Changing Gods Inter-Religious Marriage And Religious Conversion In Java, Indonesia." Indonesia and the Malay World 41, no. 119 (2013): 76-96.

Septiandani, Dian, Dharu Triasih, dan Dewi Tuti Muryani. “Legal Formulation of Marriage of Different Religions For The Benefit of Society." "Law Journal. 1, no. 2 (2017): 171-79.

Subandi. “Perkembangan Kehidupan Beragama." Buletin Psikologi 3, no. 1 (1995): 11-19. 
Rosdiana \& Ahmad Bahtiar, Preferences of Children's Religious Interfaith Marriages ...

Suhasti, Ermi, Siti Djazimah, \& Hartini. "Polemics on Interfaith Marriage in Indonesia Between Rules and Practices." Al-Jāmi'Ah: Journal of Islamic Studies 56, no. 2 (2018): 390-91.

Verma, Shewata and Neelam Sukhramani. "Interfaith Marriages and Negotiated Spaces." Society and Culture in South Asia 4, no. 1 (2017): 16-43.

Wahyuni, Sri. "Politik Hukum Pernikahan Beda Agama Di Indonesia." Jurnal Pusaka 2, no. 2 (2014): 4-15.

Zuriyati, Yaswirman, dan Yasniwati. "Registration of Interfaith Marriages at the Civil Registry Office in Pekanbaru." International Journal of Multicultural and Multireligious Understanding 6, no. 5 (2019): 895-900.

\section{Book}

Latifah, Anthin. "Perkawinan Beda Agama di Jawa Tengah: Kajian Kebijakan Hukum Terhadap Pelaksanaan Perkawinan Beda Agama di Beberapa Wilayah di Jawa Tengah," 2015.

Lie, Ian Brown. Dokumen-Dokumen Pokok Mengenai Hak Azasi Manusia. Jakarta: Universitas Indonesia, 1993.

Marcia, J.E. Ego Identity. New York: Springer, 1993.

Rosenbaum, M. Cellebrating Our Differences: Living Two Faith in One Marriage. Philadelphia: Beidel Printing, 1999.

Rozakis, L. Interfaith Relationship. Indiana: Macmilan, 2001.

Salma. "Perkawinan Campuran Antar Agama Setelah Berlakunya Undang-Undang No. 1 Tahun 1974 tentang Perkawinan.” Universitas Diponegoro, 2002.

\section{Thesis and Dissertation}

Suwasiswahyuni, Alvina. "Keabsahan Perkawinan Beda Agama yang Dilangsungkan di Luar Negeri Berdasarkan Undang-Undangn No. 1 Tahun 1974 Tentang Perkawinan dan Undang-Undang No. 23 Tahun 2006 Tentang Administrasi Kependudukan." Thesis, Universitas Indonesia, 2012.

Syamhudi, M. Hasyim. "Rumah Tangga Beda Agama: Konstruksi, Struktur dan Relasi Antar Penganut Agama Dalam Keluarga Muslim Tionghoa Probolinggo Jawa Timur." Dissertation, IAIN Sunan Ampel, 2010.

\section{Website}

icrp-online.com. “Penghulu Beda Negara Lintas Agama,” 2017.

\section{Interview}

“Interview with AN by phone," 2018.

"Interview with AO by phone," 2018.

"Interview with Mohamad Monib," 2017.

"Interview with NP by phone," 2018.

"Interview with TS by phone," 2018. 